\title{
Kecerdasan Emosional : Implikasi terhadap Kinerja Perawat di Rumah Sakit Banyumanik Semarang
}

\author{
Emotional Intelligence : Implications for The Performance of Nurses at the Banyumanik Hospital \\ Semarang
}

Hema Dewi Anggraheny ${ }^{1 *}$, Aisyah Lahdji ${ }^{1}$, Wida Faridatul ${ }^{2}$

${ }^{1}$ Dosen Fakultas Kedokteran Universitas Muhammadiyah semarang

${ }^{2}$ Mahasiswa Fakultas Kedokteran Universitas Muhammadiyah Semarang

*Penulis Korespondensi: Hema Dewi Anggraheny. Email: hemadewi@unimus.ac.id

\begin{abstract}
ABSTRAK
Latar Belakang: Penurunan pasien rawat inap di Rumah Sakit Banyumanik Semarang pada tahun 2016 sebesar $12,83 \%$ dari tahun sebelumnya sering dikaitkan dengan turunnya kepuasan terhadap pelayanan. Perawat menjadi petugas pertama yang melayani pasien rawat inap. Kinerja perawat yang optimal cenderung meningkatkan kepuasan pasien karena fokus utama perawat adalah pelayanan pasien. Faktor yang mempengaruhi kinerja perawat meliputi faktor internal dan eksternal. Kecerdasan merupakan faktor internal yang mempengaruhi tingkah laku individu yakni kecerdasan spiritual, emosional, intelektual dan adversitas. Penelitian ini bertujuan untuk mengetahui pengaruh faktor kecerdasan terhadap kinerja Perawat di Rumah Sakit Banyumanik Semarang.

Metode: Penelitian ini merupakan observasional analitik dengan pendekatan cross-sectional. Penelitian dilaksanakan pada bulan Februari 2020. Sampel penelitian adalah 35 perawat di Rumah Sakit Banyumanik Semarang. Pengambilan data masing-masing variabel menggunakan kuesioner yang sudah tervalidasi. Analisis bivariat antar variabel diuji menggunakan uji Korelasi Pearson, dan dilanjutkan analisis multivariat menggunakan regresi linier berganda.

Hasil: Terdapat hubungan antara kecerdasan intelektual (p-value 0,000), emosional (p-value 0,000), spiritual (p-value 0,000), dan adversitas (p-value 0,000) terhadap kinerja perawat. Kecerdasan emosional merupakan variabel yang paling berpengaruh terhadap kinerja perawat.

Kesimpulan: Kecerdasan emosional menjadi faktor yang paling berpengaruh terhadap kinerja perawat di Rumah Sakit Banyumanik Semarang.
\end{abstract}

Kata Kunci: Kinerja Perawat, Kecerdasan Intelektual, Emosional, Spiritual, Adversitas.

\section{ABSTRACT}

Background: The decreasing number of inpatients at the Banyumanik Hospital Semarang in 2016 by $12,83 \%$ from the previous year is often associated with decreased satisfaction with services. Nurses become the first officers to serve inpatients. Optimal nurse performance tends to increase patient satisfaction because the main focus of nurses is patient care. Factors that influence nurse performance include internal and external factors. Intelligence is an internal factor that affects individual behavior, one of which is emotional intelligence. This study aims to determine the effect of internal factors including emotional intelligence on the performance of nurses at Banyumanik Hospital Semarang.

Methods: This study was an analytic observational research with cross-sectional approach. The study was conducted in February 2020. The research sample was 35 nurses at the Banyumanik Hospital Semarang. Collecting data for each variable was using a validated questionnaire. Bivariate analysis between variables was tested using Pearson Correlation, and continued with multivariate analysis using multiple linear regression.

Results: There was a relationship between intellectual intelligence (p-value 0,000), emotional (p-value 0,000), spiritual ( $p$-value 0,000), and adversity ( $p$-value 0,000) on nurse performance. Emotional intelligence was the variable that most influences the nurse's performance.

Conclusion: Emotional intelligence is the most influential factor on the performance of nurses in Banyumanik Hospital Semarang.

Keywords: Nurse Performance, Intellectual Intelligence, Emotional, Spiritual, Adversity 


\section{PENDAHULUAN}

Jumlah pasien di Rumah Sakit Banyumanik Semarang mempunyai angka yang fluktuatif dari tahun 2016 sampai 2018. Penurunan jumlah pasien rawat inap sebesar 12,83\% pada tahun 2016. ${ }^{1}$ Penurunan jumlah pasien tersebut sering dikaitkan dengan turunnya tingkat kepuasan pasien. Kepuasan pasien yang turun dikaitkan dengan keluhan yang dialami pasien selama mendapatkan pelayanan di rumah sakit. Keluhan-keluhan pasien yang didapatkan dari bagian humas Rumah Sakit Banyumanik antara lain lahan parkir kurang memadai, petugas kurang ramah atau kurang tanggap dengan kebutuhan pasien serta waktu pelayanan obat lama. ${ }^{1}$

Jumlah petugas di rumah sakit, sebesar 40-60\%, didominasi oleh perawat. Pelayanan yang diberikan perawat menjadi faktor penting yang akan membekas terhadap pengalaman pasien. Perawat menjadi orang pertama yang berada di samping pasien rawat inap untuk memenuhi segala kebutuhan pasien selama di rumah sakit. Perawat bertugas selama 24 jam melayani pasien rawat inap. Kinerja perawat yang optimal cenderung meningkatkan kepuasan pasien karena fokus utama perawat adalah pelayanan pasien. Dengan meningkatnya kepuasan pasien, meningkat pula kualitas pelayanan rumah sakit. ${ }^{2,3}$

Penilaian kinerja perawat ditinjau dari 2 aspek yaitu secara kualitas dan kuantitas. Aspek kualitas meliputi kualitas praktik keperawatan, kualifikasi pendidikan perawat, praktik profesional perawat, collegiality, kolaborasi, tindakan etik, penggunaan sumber daya dan penelitian. Aspek kuantitas meliputi kualitas produk, jasa, pelayanan, lokasi dan fasilitas. $^{4}$

Penilaian kinerja perawat tidak luput dari beberapa faktor yang mempengaruhinya. Secara garis besar terdapat dua faktor yang mempengaruhi kinerja perawat, yaitu faktor internal dan eksternal. Faktor internal merupakan faktor yang berhubungan dengan kecerdasan, kondisi emosional, karakteristik individu seperti usia, jenis kelamin, pengalaman kerja, serta sifat seseorang meliputi sikap dan kepribadian. Faktor eksternal meliputi lingkungan yang menyertai individu tersebut seperti budaya, lingkungan pekerjaan yang meliputi beban kerja, organisasi lingkungan tempat kerja, relasi kerja, dan lainnya yang berhubungan dengan aktifitas sehari-hari individu tersebut. ${ }^{4}$

Kecerdasan merupakan salah satu dari komponen faktor internal perawat. Hasil penelitian sebelumnya menyebutkan nilai yang tinggi dalam kecerdasan emosional, ${ }^{5,6,7,8,12,13}$ kecerdasan intelektual, $5,7,12,13$ kecerdasan spiritual $^{15,8,9,13}$ dan kecerdasan adversitasnya ${ }^{10,11}$ akan cenderung memiliki kinerja yang baik dibandingkan dengan yang memiliki nilai skor yang kurang atau sama dengan rata-rata. 5,7,12,14 Perawat rentan mendapatkan stressor yang berkaitan dengan tugasnya sehari-hari. Perawat menjadi tumpuan atau lini pertama dalam melayani pasien. Tugas pelayanan dan sekaligus administrasi yang diterima perawat menjadi stressor tersendiri bagi perawat. Tingkat kecerdasan yang seimbang antara intelektual, spiritual, emosional, dan adversitas akan mempengaruhi pola pikir dan mekanisme pengaturan emosi seseorang dalam menghadapi stressor yang dialami. ${ }^{7,8,9,12}$

Belum ada penelitian serupa yang menghubungkan langsung dari keempat kecerdasan yakni kecerdasan emosional, intelektual, spiritual, dan adversitas terhadap kinerja perawat. Peneliti tertarik untuk meneliti keempat faktor kecerdasan meliputi pengaruh kecerdasan emosional, intelektual, spiritual, dan adversitas, serta menganalisis faktor kecerdasan yang paling berpengaruh diantara keempat kecerdasan tersebut terhadap kinerja perawat.

\section{METODE}

Penelitian ini sudah mendapatkan persetujuan etik dari Komite Etik Fakultas Kedokteran Unimus dengan No. 016/EC/FK/2020. Penelitian ini merupakan penelitian kuantitatif, menggunakan jenis desain penelitian observasional analitik 
dengan rancangan cross-sectional. Sampel penelitian yaitu 35 perawat di Rumah Sakit Banyumanik Semarang dengan menggunakan teknik pengambilan sampel yaitu purposive sampling. Kriteria inklusi sampel yaitu perawat di RS Banyumanik Semarang yang bersedia sebagai sampel penelitian, dan merupakan perawat fungsional tetap rumah sakit. Kriteria eksklusi yaitu perawat yang tidak mengisi kuesioner secara lengkap. Variabel bebas antara lain kecerdasan intelektual, kecerdasan emosional, kecerdasan spiritual, dan kecerdasan adversitas. Variabel perancu yaitu usia dan lama bekerja. Variabel terikat yaitu kinerja perawat. Instrumen yang digunakan adalah kuesioner terkait penilaian kecerdasan intelektual, kecerdasan emosional, kecerdasan spiritual, kecerdasan adversitas, dan kinerja perawat yang sudah tervalidasi pada penelitian sebelumnya.

Kuesioner kinerja perawat meliputi pertanyaan terkait diagnosis keperawatan, kemampuan pengkajian perawatan, perencanaan keperawatan, pelaksanaan keperawatan, dan evaluasi keperawatan. Kuesioner kecerdasan emosional meliputi pertanyaan menilai kemampuan mengenali emosi diri, mengelola emosi, memotivasi diri sendiri, mengenali emosi orang lain, dan membina hubungan. ${ }^{12}$ Kecerdasan intelektual meliputi pertanyaan menilai kemampuan figure, verbal dan numerik. ${ }^{13}$ Kecerdasan spiritual meliputi pertanyaan menilai kemampuan jujur, keterbukaan, pengetahuan diri, fokus pada kontribusi, dan spiritual nondogmatis. ${ }^{13}$ Kecerdasan adversitas meliputi pertanyaan menilai kemampuan control, origin and ownership, reach, dan endurance. ${ }^{14}$

Sebelum dilakukan analisis antar variabel, dilakukan uji normalitas menggunakan uji Kolmogorof Smirnov. Pengaruh variabel kecerdasan intelektual, emosional, spiritual, dan adversitas terhadap kinerja perawat dianalisis menggunakan uji Korelasi Pearson. Faktor yang paling berpengaruh dari variabel bebas didapatkan dari hasil uji Regresi Linier Berganda.

\section{HASIL DAN PEMBAHASAN}

\section{Hasil}

Hasil uji normalitas dari keseluruhan variabel menunjukkan nilai $\mathrm{p} \geq 0,05$, sehingga dapat disimpulkan distribusi normal. Pada tabel 1 menunjukkan data karakteristik perawat sebagian besar berjenis kelamin perempuan, dengan kualifikasi pendidikan sebagian besar adalah D3.

Tabel 1. Distribusi frekuensi jenis kelamin dan pendidikan

\begin{tabular}{lcc}
\hline \multicolumn{1}{c}{ Karakteristik } & $\mathrm{n}$ & $\%$ \\
\hline Jenis kelamin & & \\
Perempuan & 24 & 68,8 \\
Laki-laki & 11 & 31,4 \\
\hline Pendidikan & & \\
D3 & 31 & 88,6 \\
S1 & 4 & 11,4 \\
\hline
\end{tabular}

Tabel 2 menunjukkan usia responden rata-rata 30 tahun, dengan lama bekerja ratarata 7 tahun. Rata-rata nilai kinerja perawat tergolong baik. Rata-rata kecerdasan intelektual perawat tergolong di tingkat sedang. Rata-rata kecerdasan emosional perawat tergolong di tingkat sedang. Rata-rata kecerdasan spiritual perawat tergolong di tingkat tinggi. Rata-rata kecerdasan adversitas perawat tergolong di tingkat sedang. 
Tabel 2. Karakteristik perawat

\begin{tabular}{lcc}
\hline \multicolumn{1}{c}{ Karakteristik } & $\mathrm{n}$ & Min-max $($ mean \pm sd $)$ \\
\hline Usia & 35 & $23-43(30,83 \pm 5,909)$ \\
Lama bekerja & 35 & $1-20(7,40 \pm 5,419)$ \\
Kinerja & 35 & $92-116(107,71 \pm 6,364)$ \\
Kecerdasan emosional & 35 & $25-37(30,40 \pm 2,992)$ \\
Kecerdasan intelektual & 35 & $22-35(29,63 \pm 3,317)$ \\
Kecerdasan spiritual & 35 & $25-40(31,46 \pm 3,441)$ \\
Kecerdasan adversitas & 35 & $67-95(80,26 \pm 6,247)$ \\
\hline
\end{tabular}

Tabel 3 menunjukkan hasil analisis bivariat antara variabel kecerdasan intelektual, emosional, spiritual, adversitas terhadap kinerja perawat menunjukkan hasil yang signifikan dengan nilai $r$ rata-rata menunjukkan arah hubungan yang positif kuat. Variabel usia dan lama bekerja tidak menunjukkan hubungan yang signifikan terhadap kinerja perawat.

Tabel 3. Analisis antar variabel

\begin{tabular}{llcc}
\hline \multirow{2}{*}{ No } & \multirow{2}{*}{ Komponen yang diteliti } & \multicolumn{2}{c}{ Kinerja Perawat } \\
\cline { 3 - 4 } & & $\begin{array}{c}\text { Koefisien } \\
\text { korelasi (r) }\end{array}$ & P-value \\
\hline 1 & Kecerdasan Intelektual & 0,709 & $0,000^{* \#}$ \\
\hline 2 & Kecerdasan Emosional & 0,782 & $0,000^{* \#}$ \\
\hline 3 & Kecerdasan Spiritual & 0,699 & $0,000^{* \#}$ \\
\hline 4 & Kecerdasan Adversitas & 0,785 & $0,000^{* \#}$ \\
\hline 5 & Usia & 0,223 & $0,198^{*}$ \\
\hline 6 & Lama Bekerja & 0,183 & $0,292^{*}$ \\
\hline
\end{tabular}

Keterangan : *Uji Korelasi pearson, hasil signifikan ( $\mathrm{p}$-value $\leq 0,05$ )

Uji multikolinieritas, heterokedastisitas, dan koefisiens determinasi telah memenuhi persyaratan untuk uji regresi linier berganda. Uji multivariat ini adalah untuk mencari faktor yang paling berpengaruh. Hasil uji multivariat menunjukkan variabel yang tereksklusi antara lain kecerdasan spiritual, intelektual, dan adversitas sehingga dapat disimpulkan kecerdasan emosional merupakan faktor yang paling berpengaruh terhadap kinerja perawat.

Tabel 4. Uji multivariat (exclude variable)

\begin{tabular}{clccccc}
\hline \multirow{2}{*}{ Model } & & & & & & \multicolumn{2}{c}{ Collinearity Statistics } \\
\cline { 4 - 7 } 1 & & Beta In & T & Sig. & Partial Correlation & Tolerance \\
\cline { 2 - 7 } 1 & Kecerdasan Intelektual & $0,436^{\mathrm{b}}$ & 4,393 & 0,000 & 0,613 & 0,772 \\
\cline { 2 - 7 } & Kecerdasan Spiritual & $0,357^{\mathrm{b}}$ & 2,899 & 0,007 & 0,456 & 0,635 \\
\hline \multirow{2}{*}{2} & Kecerdasan Adversitas & $0,494^{\mathrm{b}}$ & 5,224 & 0,000 & 0,678 & 0,735 \\
\hline
\end{tabular}


Tabel 4. Uji multivariat (exclude variable)

\begin{tabular}{ccccccc}
\hline & & & & & & \multicolumn{2}{c}{ Collinearity Statistics } \\
\cline { 5 - 7 } Model & & Beta In & T & Sig. & Partial Correlation & Tolerance \\
\hline 3 & Kecerdasan Spiritual & $0,245^{\mathrm{d}}$ & 2,842 & 0,008 & 0,461 & 0,570 \\
\hline
\end{tabular}

\section{Pembahasan}

Hasil penelitian ini menunjukan bahwa terdapat korelasi yang signifikan antara kecerdasan intelektual, emosional, spiritual, dan adversitas terhadap kinerja perawat. Sifat dan arah hubungan dari keempat variabel tersebut menunjukkan hasil yang hampir sama dengan arah hubungan positif kuat. Hal tersebut dapat diartikan bahwa semakin tinggi tingkat kecerdasan maka akan meningkatkan kinerja perawat. Hasil tersebut sejalan dengan penelitian sebelumnya yang menyebutkan bahwa kecerdasan intelektual dan emosional berhubungan positif terhadap kinerja perawat. $^{5,6,7,12}$

Individu yang cenderung memiliki kecerdasan intelektual tinggi akan lebih mudah mencerna dan membentuk pola pikir untuk dapat menyelesaikan permasalahan yang berkaitan dengan pekerjaannya. ${ }^{5,12}$ Kecerdasan emosional juga berpengaruh dengan kinerja dikarenakan individu dengan kecerdasan emosional baik akan memiliki kemampuan untuk dapat menyelesaikan konflik dan emosi dirinya serta bagaimana menerapkan emosinya saat berhadapan dengan orang lain. Perawat tidak lepas dari pelayanan langsung dengan pasien yang membutuhkan rasa emosional yang mendalam terhadap pekerjaan. Emosional yang positif akan lebih menggerakkan perawat untuk dapat melayani dengan tulus sehingga akan membekas positif pada pasien. ${ }^{5-8,12}$

Hasil penelitian ini juga mendukung penelitian sebelumnya yang menyebutkan terdapat pengaruh signifikan antara kecerdasan spiritual dengan kinerja perawat. $^{5,8,9}$ Perawat dengan kecerdasan spiritual yang mumpuni akan mengerjakan pekerjaannya sebaik mungkin, sesuai dengan nilai-nilai spiritual yang diyakininya antara lain menjunjung tinggi kebenaran, kepercayaan dan kejujuran. Kecerdasan spiritual dengan sendirinya akan menghasilkan kebaikan dan kinerja yang optimal karena dikaitkan dengan semua hal yang dilakukan termasuk pekerjaan sehariharinya merupakan bentuk ibadah. Hal ini membuat individu tersebut akan selalu berusaha memberikan yang terbaik. ${ }^{5,9,8}$

Perawat dengan kecerdasan adversitas yang tinggi memiliki manajemen mengendalikan konflik yang ada pada dirinya. Seseorang dengan kecerdasan adversitas yang baik akan dapat mengidentifikasi masalah yang dihadapi secara positif, menelaah akar permasalahan, dan mengambil tindakan yang tepat untuk mengatasi permasalahan dirinya. ${ }^{10,14}$

Usia dan lama bekerja pada penelitian ini tidak memiliki hubungan signifikan terhadap kinerja perawat. Hasil penelitian ini sejalan dengan penelitian sebelumnya. ${ }^{4}$ Hasil tersebut membuktikan bahwa usia dan lama bekerja tidak dapat dikaitkan dengan kinerja. Belum tentu seseorang dengan usia yang lebih tua dan waktu bekerja yang lebih lama akan selalu mempunyai kinerja lebih baik.

Kecerdasan emosional merupakan variabel yang paling berpengaruh terhadap kinerja perawat di Rumah Sakit Banyumanik Semarang. Hasil penelitian tersebut menunjukkan pada perawat kemampuan yang seharusnya dimiliki lebih dari kemampuan lainnya yaitu kemampuan dalam mengolah emosinya. Hal ini berkaitan erat dengan kinerja perawat yang cenderung di pelayanan pasien. Pasien akan selalu merespon dengan bagaimana secara emosional ikatan antara dirinya dengan perawat terbangun, sehingga akan meningkatkan motivasi dan kepercayaan dirinya untuk sembuh dari penyakit yang dideritanya. ${ }^{6,8,15}$

\section{KESIMPULAN DAN SARAN}




\section{Kesimpulan}

Kecerdasan emosional merupakan faktor yang paling berpengaruh terhadap kinerja perawat Rumah Sakit Banyumanik Semarang. Semakin tinggi kecerdasan emosional yang dimiliki akan semakin meningkatkan kinerja perawat.

\section{Saran}

Saran untuk pihak rumah sakit, penelitian ini dapat sebagai masukan dalam penentuan persyaratan rekruitmen perawat, dengan memperhitungkan penilaian dengan melihat hasil keempat kecerdasan yang dimiliki.

\section{DAFTAR PUSTAKA}

1. Akbar SZ, Sri S. Pengaruh kualitas pelayanan dan tarif terhadap layanan pasien melalui kepuasan pasien (studi kasus pada Rumah Sakit Banyumanik Semarang). Diponegoro Jurnal of Social and Political Science. 2018;2:585-92.

2. Potter PA, Perry AG. Buku ajar fundamental keperawatan : konsep, proses, dan praktik. Edisi 7. Volume 2. EGC. Jakarta : 2014.

3. Zulkarnain. Analisis pelaksanaan fungsi manajemen pengarahan kepala ruangan dengan kinerja perawat dalam menerapkan asuhan keperawatan di ruang rawat inap RSUD Bima. Jurnal Ilmu Sosial dan Pendidikan. November 2017;1(2).

4. Mandagi FM, Umboh JML, Rattu J. Analisis faktor-faktor yang berhubungan dengan kinerja perawat dalam menerapkan asuhan keperawatan di Rumah Sakit Umum Bethesda GMM Tomohon. Jurnal e-Biomedik. September 2015; 3(3).

5. 5. Hirfa T. Hubungan antara kecerdasan intelektual (IQ), kecerdasan emosional (EQ), kecerdasan spiritual (SQ) dengan kinerja bidan di Rumah Sakit Islam Jakarta. Jurnal Pengabdian Masyarakat. 2016;1 (2).
6. Al-Faouri I, Codier E. Correlating emotional intelligence and job performance among Jordanian Hospitals' Registered nurses. Nursing Forum. 2016; 52(1).

7. So-Hee P, Min-Jeong P. The effects of emotional intelligence, nursing work environment on nursing work performance in clinical nurses. Journal of Digital Convergence. 2018;16(4):175-84.

8. Haryono S, Rosady F, MdSaad MS. Effects of emotional and spiritual intelligence on job performance among temporary nurses at Abdul Riva'I Regional General Hospital, Berau District, East Kalimantan Province, Indonesia. Management Issues in Healthcare System. 2018;4:42-54.

9. Khahdan M, Eyni Z, Koohpaeni A. Relationship between Spiritual Intelligence and Job Performance: A Case Study of Nurses and Nursing Aids in the Main University Hospital of Qom, Iran. Health Spiritual Med Ethics. 2017; 4(3):8-13. Available From URL: HIPERLINK

http://jhsme.muq.ac.ir/article-1-152-

fa.html

10. Solfema. Adversity intelligence as a contributing factor of tutor's performance. European Journal of Education Studies. 2017; 3(11): 840-7.

11. Verma S, Aggarwal A, Bansal H. The relationship between emotional intelligence (EQ) and adversity quotient (AQ). IOSR Journal of Business and Management. 2017;19(1):49-53.

12. Yenti Novri, Machasin, Amsal Chairul. Pengaruh kecerdasan emosional, kecerdasan intelektual, dan disiplin terhadap kinerja perawat pada RS PMC Pekanbaru. Jom FEKON. 2014;1(2).

13. Rahmasari, Lisda. Pengaruh kecerdasan intelektual (IQ), kecerdasan emosi (EQ), dan kecerdasan spiritual (SQ) terhadap kinerja karyawan majalah ilmu informatika.2012;3(3).

14. Utami EW, Dewanto A. Pengaruh adversity quotient terhadap kinerja 
perawat dengan motivasi kierja sebagai variabel mediasi (Studi di RSUD "Ngudi Waluyo" Wlingi). Jurnal Aplikasi Manajemen.2013;2 (1). ISSN 1693-5241.

15. Anggraheny HD, Sudiro. The childbirth services aspect that influence patient satisfaction. Kemas. 2017;12(2):96-104. 